\title{
Undergraduate Certificate in Equine Science and Management
}

\section{DOI:10.31274/air.13022}

\author{
Peggy Auwerda, Associate Professor; \\ Nikki Ferwerda, Associate Professor of Teaching, Equine \\ Farm Manager; \\ Jill Paxton, Assistant Professor; \\ Jennifer M. Bundy, Assistant Professor; \\ Elisabeth Huff-Lonergan, Professor; \\ Jodi A. Sterle, Professor; \\ Joan E. Cunnick, Professor; \\ Christen G. Burgett, Associate Teaching Professor; \\ Laura L. Greiner, Assistant Professor; \\ Elizabeth A. Bobeck, Assistant Professor; \\ Nicholas K. Gabler, Professor; \\ Steven M. Lonergan, Morrill Professor; \\ Department of Animal Science, Iowa State University
}

\section{Summary and Implications}

Iowa State University offers undergraduate certificates to demonstrate completion of a focused study in a specialized area. The certificate has the significant benefit of allowing students to customize their curriculum and document an approved course of study. An Equine Science and Management Certificate is offered within the Animal Science Department at Iowa State University. The certificate requirements are organized to correspond with faculty and employer-defined needs for a successful transition from student to equine industry professional.

The Equine Science and Management certificate will integrate technical topics in animal science with practical considerations in enterprise management. Two critical components to the certificate are the capstone Equine Systems Management course and a required internship in equine science and management. Students that complete the certificate will have the background to identify and address challenges in modern equine enterprises. Further, the certificate assists employers in identifying students that have shown the interest, discipline, and ability to complete this specialized study program.

\section{Introduction}

The U.S. equine industry generates approximately $\$ 122$ billion in total economic impact. The USDA 2017 Census of Agriculture reported nearly 55,000 horses, ponies, mules, and donkeys on more than 9,000 farms in Iowa. The state's total sales of equine were $\$ 19.7$ million, ranking Iowa 11 th in the nation. In the United States, currently, there are an estimated 7.2 million horses. Also, 38 million, or $30.5 \%$, of U.S. households contain a horse enthusiast. Students with documented expertise in this certificate program will be ready to contribute to this growing industry.

Responsible and effective breeding and health management contributes to the equine industry's vitality, supports efforts to improve animal welfare; and increases the awareness of recreational use of horses for sport, companionship, competition, and entertainment. Therefore, successful equine management contributes to a growing agricultural economy. The demand for professionals with expertise in equine production management is rising and is acutely evident. Expertise is necessary for traditional production venues and expands to animal welfare, the horsehuman bond, and aspects of competition and sport.

\section{Approach}

The objective was to develop an equine science and management course of study within the requirements of an undergraduate certificate. Students that complete the certificate will be able to:

a. Demonstrate a breadth of understanding of nutrition, physiology, and breeding applications in modern equine systems.

b. Evaluate systems and provide solutions to ensure the efficient management of an equine operation.

c. Recognize issues that affect the utilization of natural resources in equine systems.

d. Demonstrate competence in hands-on and practical applications in their field.

e. Demonstrate the development of the knowledge, skills, and abilities necessary for a career position in equine management.

\section{Requirements of the Equine Science and Management Certificate}

The Equine Science and Management Certificate program prompts students to customize their certificate with specific scientific disciplines and management practices. This 24-credit certificate provides the appropriate background and context for students to develop their equine science and management expertise.

The certificate requirements are organized to correspond with faculty and employer-defined needs for a successful transition from student to equine industry professional. The program integrates equine management principles with foundation disciplines in animal science. All

Copyright (C) 2021 by the Authors. This is an open access article published under the CC BY-NC license (https://creativecommons.org/licenses/by-nc/4.0/), which allows for non-commercial reuse with proper attribution. 
courses in the certificate are available, and full descriptions are available in the Iowa State University Catalog (https://catalog.iastate.edu).

The certificate requires completion of courses within the following categories: Foundation Course (3 Credits), Fundamental Disciplines in Animal Science (6 credits), Equine Expertise Expansion (6 credits), Expertise Expansion (3 credits), and Equine Management Emphasis (6 credits). Per ISU policy, nine credits will be unique to the certificate and will not be applied to a major, minor, or another certificate.

\section{Availability of the Equine Science and Management Certificate}

The Equine Science and Management Certificate has been approved by the Department of Animal Science Curriculum Committee, the College of Agriculture and Life Sciences College Curriculum committee, and the Faculty Senate. Therefore, the Equine Science and Management Certificate will be available to ISU undergraduate students beginning in the fall of 2021 .

\section{EQuine Science ANd MANagement Certificate} (24 CREDITS)

\begin{tabular}{|c|c|c|}
\hline \multicolumn{2}{|c|}{ Foundation Course (3 credits) } & \multirow{2}{*}{$\begin{array}{r}\text { Credits } \\
3\end{array}$} \\
\hline ANS 216 & Equine Science & \\
\hline \multicolumn{3}{|c|}{ Fundamental Disciplines (6 credits) } \\
\hline AN S 320 & Animal Feeds and Feeding & 3 \\
\hline AN S 331 & $\begin{array}{l}\text { Domestic Animal } \\
\text { Reproduction }\end{array}$ & 3 \\
\hline \multicolumn{3}{|c|}{ Equine Expertise Expansion (6 Credits) } \\
\hline ANS 217 & Equine Farm Practicum & 2 \\
\hline An S 306 & Equine Evaluation & 3 \\
\hline An S 313 & $\begin{array}{l}\text { Exercise Physiology of } \\
\text { Animals }\end{array}$ & 2 \\
\hline An S 317A & $\begin{array}{l}\text { Fundamentals of Equine } \\
\text { Behavior and Training: } \\
\text { Young Horses at Halter }\end{array}$ & 1 \\
\hline An S 317B & $\begin{array}{l}\text { Fundamentals of Equine } \\
\text { Behavior and Training: } \\
\text { Yearlings }\end{array}$ & 3 \\
\hline An S 332E & $\begin{array}{l}\text { Laboratory Methods in } \\
\text { Animal Reproduction - } \\
\text { Equine }\end{array}$ & 1 \\
\hline \multicolumn{3}{|c|}{ Expertise Expansion (3 Credits) } \\
\hline ACCT 215 & $\begin{array}{l}\text { Legal Environment of } \\
\text { Business }\end{array}$ & 3 \\
\hline AGEDS 451 & Agricultural Law & 3 \\
\hline AGRON 334 & Forage Crop Management & 3 \\
\hline AN S 333 & $\begin{array}{l}\text { Embryo Transfer and } \\
\text { Related Technologies }\end{array}$ & 3 \\
\hline AN S 336 & $\begin{array}{l}\text { Domestic Animal Behavior } \\
\text { and Well-Being }\end{array}$ & 3 \\
\hline AN S 337 & Lactation & 3 \\
\hline AN S 345 & $\begin{array}{l}\text { Growth and Development of } \\
\text { Domestic Animals }\end{array}$ & 3 \\
\hline ECON 230 & Farm Business Management & 3 \\
\hline ECON 334 & $\begin{array}{l}\text { Entrepreneurship in } \\
\text { Agriculture }\end{array}$ & 3 \\
\hline \multicolumn{3}{|c|}{ Equine Management Emphasis (6 credits) } \\
\hline AN S 415 & $\begin{array}{l}\text { Equine Systems } \\
\text { Management }\end{array}$ & 3 \\
\hline ANS 399 & $\begin{array}{l}\text { Equine Internship } \\
\text { Experience }\end{array}$ & 3 \\
\hline
\end{tabular}

